\title{
UNIFFERENTIATED CONNECTIVE TISSUE DYSPLASIA AS A POTENTIAL PREDICTOR OF ARTERIAL HYPERTENSION DEVELOPMENT IN PATIENTS WITH TYPE 2 DIABETES MELLITUS
}

\author{
Ludmila Sherstyuk, Yevgen Nikolenko \\ V. N. Karazin Kharkiv National University, 6 Svobody Sq., Kharkiv, 61022, Ukraine, \\ e-mail: med@karazin.ua
}

The article presents the results of studies of markers of connective tissue dysplasia and the content of the main fibroblast growth factor in blood plasma in patients with type 2 diabetes. The presence of significant correlations between the studied parameters with the occurrence and progression of hypertension in patients with type 2 diabetes is established. A regression model for predicting the development of arterial hypertension is proposed in patients with diabetes mellitus.

KEY WORDS: arterial hypertension, type 2 diabetes mellitus, undifferentiated connective tissue dysplasia, basic fibroblast growth factor, prediction

\section{НЕДИФЕРЕНЦЙОВАНА ДИСПЛАЗІЯ СПОЛУЧНОЇ ТКАНИНИ ЯК ПОТЕНЦЙНИЙ ПРЕДИКТОР РОЗВИТКУ АРТЕРІАЛЬНОЇ ГІПЕРТЕНЗІЇ У ХВОРИХ НА ЦУКРОВИЙ ДІАБЕТ 2 ТИПУ}

Шерстюк Л. Л., Ніколенко С. Я.

Харківський національний університет імені В. Н. Каразіна, пл. Свободи, 6, м. Харків, 61022, Україна

У статті наведено результати досліджень маркерів дисплазії сполучної тканини та вмісту основного фактору росту фібробластів в плазмі крові у хворих на цукровий діабет 2 типу. Встановлено наявність достовірних кореляцій між вивчаємими показниками 3 виникненням та прогресування артеріальної гіпертензії у хворих на цукровий діабет 2 типу. Запропоновано регресійну модель для прогнозування розвитку артеріальної гіпертензії у хворих на цукровий діабет.

КЛЮЧОВІ СЛОВА: артеріальна гіпертензія, цукровий діабет 2 типу, недиференційована дисплазія сполучної тканини, основний фактор росту фібробластів, прогнозування

\section{НЕДИФФЕРЕНЦИРОВАННАЯ ДИСПЛАЗИЯ СОЕДИНИТЕЛЬНОЙ ТКАНИ КАК ПОТЕНЦИАЛЬНЫЙ ПРЕДИКТОР РАЗВИТИЯ АРТЕРИАЛЬНОЙ ГИПЕРТЕНЗИИ У БОЛЬНЫХ САХАРНЫМ ДИАБЕТОМ 2 ТИПА}

Шерстюк Л. Л., Николенко Е. Я.

Харьковский национальный университет имени В. Н. Каразина, пл. Свободы, 6, г. Харьков, 61022, Украина

В статье приведены результаты исследований маркеров дисплазии соединительной ткани и содержания основного фактора роста фибробластов в плазме крови у больных сахарным диабетом 2 типа. Установлено наличие достоверных корреляций между изучаемыми показателями с возникновением и прогрессирования артериальной гипертензии у больных сахарным диабетом 2 типа. Предложено регрессионную модель для прогнозирования развития артериальной гипертензии у больных сахарным диабетом.

КЛЮЧЕВЫЕ СЛОВА: артериальная гипертензия, сахарный диабет 2 типа, недифференцированная дисплазия соединительной ткани, основной фактор роста фибробластов, прогнозирование

\section{INTRODUCTION}

(C) Sherstyuk L. L., Nikolenko, Ye. Ya., 2018
Arterial hypertension (AG) is one of the most common cardiovascular diseases that 
afflicts more than 1.5 billion people in the world, with almost $45 \%$ of them being not aware of the presence of high blood pressure (BP) [1]. Hypertension is often manifested in combination with another pathology, in particular, with diabetes mellitus (DM), obesity, coronary heart disease (CHD), chronic kidney disease (CKD), heart failure $(\mathrm{CH})$, and others [2-3]. The most often combination is hypertension and diabetes. The prevalence of hypertension among patients with diabetes is more than $60 \%$. Such a comorbidity significantly increases the risk of severe cardiovascular complications [4-5]. The presence of hypertension in patients with type 1 diabetes is associated with an increase in the frequency of severe stages of diabetic nephropathy and retinopathy; on the other hand, diabetes significantly increases the risk of emergence and developing hypertension, and hypertension is associated with a high risk of insulin resistance and metabolic abnormalities [6]. When combined with hypertension and diabetes, the risk of CHD developing increases by 2-4 times, stroke 2-3 times, visual loss - 10-25 times, renal insufficiency - 15-20 times, gangrene of the lower extremities - 20 times [7].

Mechanisms of damage of many organs and systems in case of diabetes and hypertension are discussed by many researchers. Endothelial dysfunction due to metabolic disorders in diabetes or long-term BP increase lead to a breach of vasodilatation, thickening of the basement membrane of microvessels, metabolic disorders in extracellular matrix and initiating of large vessels atherosclerotic lesions [8-9]. Disturbance of lipid metabolism is essential as trigger factor, in addition to hyperglycemia. The immediate damaging factors may be the end products of glycolysis (AGE), products of lipid peroxidation, increased activity of angiotensin II, proinflammatory cytokines, leukocyte adhesion factors, activation of protein kinase $C$ and others [10]. Increase of AGE, accumulation of circulating fatty acids, products of oxidative stress and dysfunction of the endothelium lead to accelerated apoptosis, reducing angiogenesis and cardiac remodeling violation [11].

S. Shakya et al. (2015) believe that the main target of hyperglycemia is hyaluronic- containing glycocalyx, located in the microvascular endothelium. Its damage leads to an increase in the adhesive properties of leukocytes and causes the formation of proinflammatory cytokines. In turn, this leads to the further development of oxidative stress and the progression of endothelial disorders with an increase in the proinflammatory cytokines release. Such a proinflammatory condition affects the function of functionally active cells (pericytes, smooth muscle cells, fibroblasts), which worsens reparative processes in vessels and tissues, including angiogenesis [12]. One of the mechanisms of the pathological effect of hyperglycemia is also thought to be the increase in the activity of prophylactic factors, in particular, TGF- $\beta$, which is a modulator of proteoglycan synthesis in the extracellular matrix [12-13]. is The increase in excretion of type IV collagen in patients with diabetes, with diabetic nephropathy and nephropathy of another genesis serves as an evidence of connective tissue metabolic abnormalities role in the extracellular matrix [14-15].

These data indicate that the target of pathological processes taking place in hypertension and diabetes is connective tissue. On the other hand, the presence of feedback is increasingly considered - the role of metabolic disorders of connective tissue in the emergence of another, in particular, vascular pathology. It is known that the connective tissue, which constitutes more than $50 \%$ of the human body mass, carries out not only the supporting-skeleton, structural-forming, protective and reparative functions in the whole organism, but also takes part in almost all processes of metabolism. Pathological activation or inhibition of the activity of cellular elements of the connective tissue and changes in the structure of the basic substance can be the basis for the development and progression of the pathological process, the emergence of its complications and the appearance of comorbid pathology [16-17].

At this time, the disease, the characteristic feature of which is the development of connective tissue disorders, are defined as connective tissue dysplasia (CTD). The genetically determined differentiated variants of CTD are known that are Ehlers-Danloss, Marfan, Sticker's syndrome, and variants of CTD with clinical manifestations that are not 
included in the clinical picture of hereditary pathology - undifferentiated CND (UCTD). Nowadays clinical variants of UCTD include numerical diseases with the presence of neurological, skeletal, cardiac, vascular, visceral, visual and other manifestations [16, 18]. The prevalence of CTD is rather high in the population, and single phenotypic symptoms are found in almost every fourth person $[16,19]$. It is believed that the presence of CTD contributes to the development of another pathology. In particular, it has been established that diabetic neuropathy and nephropathy in children and adolescents with type 1 diabetes occur earlier and have severe course of disease in the presence of signs of connective tissue dysplasia [20].

Taking into account the value of the connective tissue in ensuring of the normal structure of all organs and tissues and in the processes of tissue remodeling under conditions of pathology, it is well-founded to study the role of UCTD in the development of hypertension, in particular, in patients with type 2 diabetes.

\section{OBJECTIVE}

The purpose of the study is to study the possibility of using the clinical signs of UCTD as predictors of the development of arterial hypertension in patients with type 2 diabetes mellitus.

\section{MATERIALS AND METHODS}

The study was performed on the basis of the endocrinology department of the Kharkiv Regional Clinical Hospital. The study included 90 patients aged from 35 to 45 years who were on treatment during the period of 2016-2018 years with an established diagnosis of type 2 diabetes mellitus, lasting no more than 10 years.

All patients have undergone a complex general clinical, laboratory and instrumental examination in accordance to the Order of the Ministry of Health of Ukraine No. 1118 dated 21.12.2012 «Unified clinical protocol of primary and secondary (specialized) medical aid. Type 2 diabetes mellitus». The diagnosis of hypertension was carried out in accordance to the Order of the Ministry of Health of Ukraine No. 384 dated 24.05.2012, «Arterial Hypertension: An Updated and Adapted Clinical Invention based on Evidence».
Diagnosis of UCTD was carried out through a comprehensive examination and evaluation of the presence of internal (visceral) and external (skeletal, skin, articular) signs according to T. I. Kadurina (2009) [15].

Phenotypic (visceral and/or skeletal) signs of UCTD were found in 48 patients (Group I) among the patients included in the study and 42 patients had no signs of UCTD (Group II). The control group consisted of 20 practically healthy people - donors with an average age of $36.3 \pm 3.1$ years.

The study of the concentration of the basic fibroblast growth factor 2 (FGF2) in blood plasma was carried out by immunoassay using a Quantikine (Human FGF basic immunoassay) reagent kit manufactured by R\&D Systems, Inc. (USA) on the semiautomatic analyzer ImmunoChem 2100 in the Department of Experimental Pharmacology and Toxicology of the the SI «V. Danilevsky Institute for Endocrine Pathology Problems of the NAMS of Ukraine».

The obtained results were processed using the package of statistical software PSSR (an open-source program that does not need a license). Quantitative data is given in the form of $\mathrm{M} \pm \mathrm{SD}$ (average and standard deviation of the mean) for normal data distribution or $\mathrm{Me}\left[\mathrm{Q}_{25}-\mathrm{Q}_{75}\right]$ (median -25 th and 75th quarters) with abnormal data distribution. The normality of distribution was determined by the Kolmagorov-Smirnov criterion, amended by Liliefors. Quantitative indices with normal distribution were compared using Student's t-test, with an abnormal distribution - according to the Mann-Whitney criterion. The frequency of quality indicators was performed using criterion $\chi^{2}$. Correlation analysis performed according to Pearson criteria.

\section{RESULTS AND DISCUSSION}

It was found that the average duration of the disease did not differ significantly and was in the 1 st group $(5.1 \pm 2.3$ years $)$, in the 2nd group it was $4.2 \pm 2.6$ years $(\mathrm{p}=0.108$ per $\mathrm{t}$-criterion) according to the analysis results of the peculiarities of the course of diabetes. There was $37(77.1 \%)$ patients with a duration of diabetes up to 5 years in Group I and $29(69.0 \%)$ in group II, $11(22.9 \%)$ patients with a duration of disease from 5 to 10 years in group I, $13(31.0 \%)$ - in the 2 nd group $(\chi 2=0.740, p=0.390)($ tab. 1$)$. 
Features of diabetes mellitus based on the presence of UCTD

Table 1

\begin{tabular}{|l|c|c|c|}
\hline \multicolumn{1}{|c|}{ Indicator } & Group I $(\mathrm{n}=48)$ & Group II (n= 42) & $\mathrm{p}$ \\
\hline Duration of DM, years & $5,1 \pm 2,3$ & $4,2 \pm 2,6$ & $0,108^{1}$ \\
\hline Duration of DM: & $37(77,1 \%)$ & $29(69,0 \%)$ & $0,390^{2}$ \\
up to 5 years & $11(22,9 \%)$ & $13(31,0 \%)$ & $0,002^{2}$ \\
5-10 years old & $38(79,2 \%)$ & $20(47,6 \%)$ & $0,040^{2}$ \\
\hline Diabetic nephropathy & $17(35,4 \%)$ & $6(14,3 \%)$ & $0,184^{2}$ \\
\hline$\quad$ Microalbuminuria & $25(52,1 \%)$ & $16(38,1 \%)$ & $0,105^{2}$ \\
\hline Diabetic retinopathy & $41(85,4 \%)$ & $30(71,4 \%)$ & ${ }^{2}$ \\
\hline Diabetic neuropathy & & & \\
\hline
\end{tabular}

Notes: 1 - the significance of the difference based on the t-criterion. 2 - the significance of the difference by criterion $\chi^{2} .3$ - the significance by the Mann-Whitney criterion

Diabetic nephropathy was a frequent complication of diabetes in the analyzed sample of patients. It was diagnosed in 38 $(79.2 \%)$ patients in group I, in $20(47.6 \%)$ patients in II group $\left(\chi^{2}=9,729, \mathrm{p}=0,002\right)$. While microalbuminuria (MA) was observed in $17(35.4 \%)$ patients in group I and in 6 $(14.3 \%)$ patients in group II $\left(\chi^{2}=4,205 ; \mathrm{p}=\right.$ $0,040)$.

Thus, there is more severe course of diabetes with more frequent development of diabetic nephropathy with MA, as well as with the tendency to increase the incidence of diabetic neuropathy and retinopathy in patients with the signs of the UCTD.
The most common accompanying pathology in the analyzed group of patients was hypertension, which was detected in 45 $(93.7 \%)$ patients in group I, including: stage 1 hypertension - in $25(52.1 \%)$, stage 2 hypertension - in $17(35.4 \%)$ and stage 3 hypertension - in $3(6.3 \%)$ patients. Hypertension was detected in $22(52.4 \%)$ patients in the II group including: $16(38,1 \%)$ patients with stage 1 hypertension, $5(11,9 \%)$ - with stage 2 hypertension, $1(2.4 \%)$ - with stage 3 hypertension $(\chi 2=21.783 ; p<0.001)$ (fig. 1).

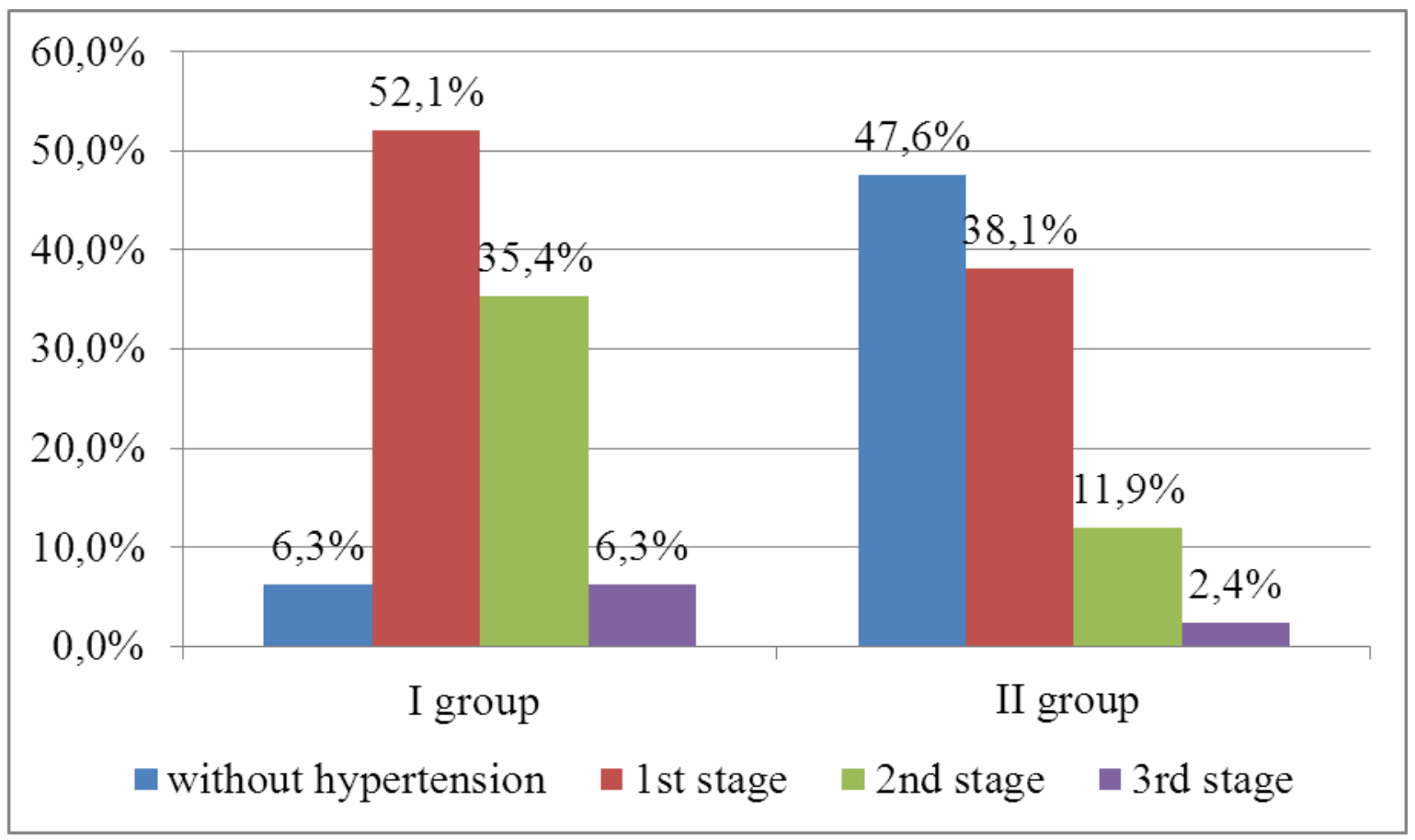

Fig. 1. Frequency and severity of hypertension in I and II groups of patients 
Certain patterns have been identified depending on the duration of diabetes as a result of the analysis of the frequency and severity of hypertension. No differences in the frequency of hypertension of varying stages depending on the duration of diabetes was detected in group I (with the presence of UCTD) $\left(\chi^{2}=1,603 ; p=0,659\right)$. On the contrary, clear dependence of hypertension stages on the duration of diabetes can be traced in patients of II group (without phenotypic signs of UCTD) - the frequency of hypertension itself and 2nd and 3rd stages significantly increases $\quad(\chi 2=17,961$; $\mathrm{p}<0,001)$ in patients with a duration of diabetes from 5 to 10 years in comparison with patients whose disease lasted less than 5 years old. These patterns are confirmed by the results of the correlation analysis: a very weak positive correlation was found at the level $r_{S}=0.091(\mathrm{p}=0.538)$ in the I group and there was a significant positive correlation at $r_{S}=0.522(\mathrm{p}<0.001)$ in the II group.

The comparison of frequencies of UCTD cases was performed depending on the presence of visceral and/or skeletal signs for a more detailed study of the effect of UCTD on the development of hypertension in patients with type 2 diabetes. Only visceral signs of UCTD were detected in 31 patients in the Ia group, visceral and skeletal symptoms were detected in 17 patients who were Ib group (fig. 2).

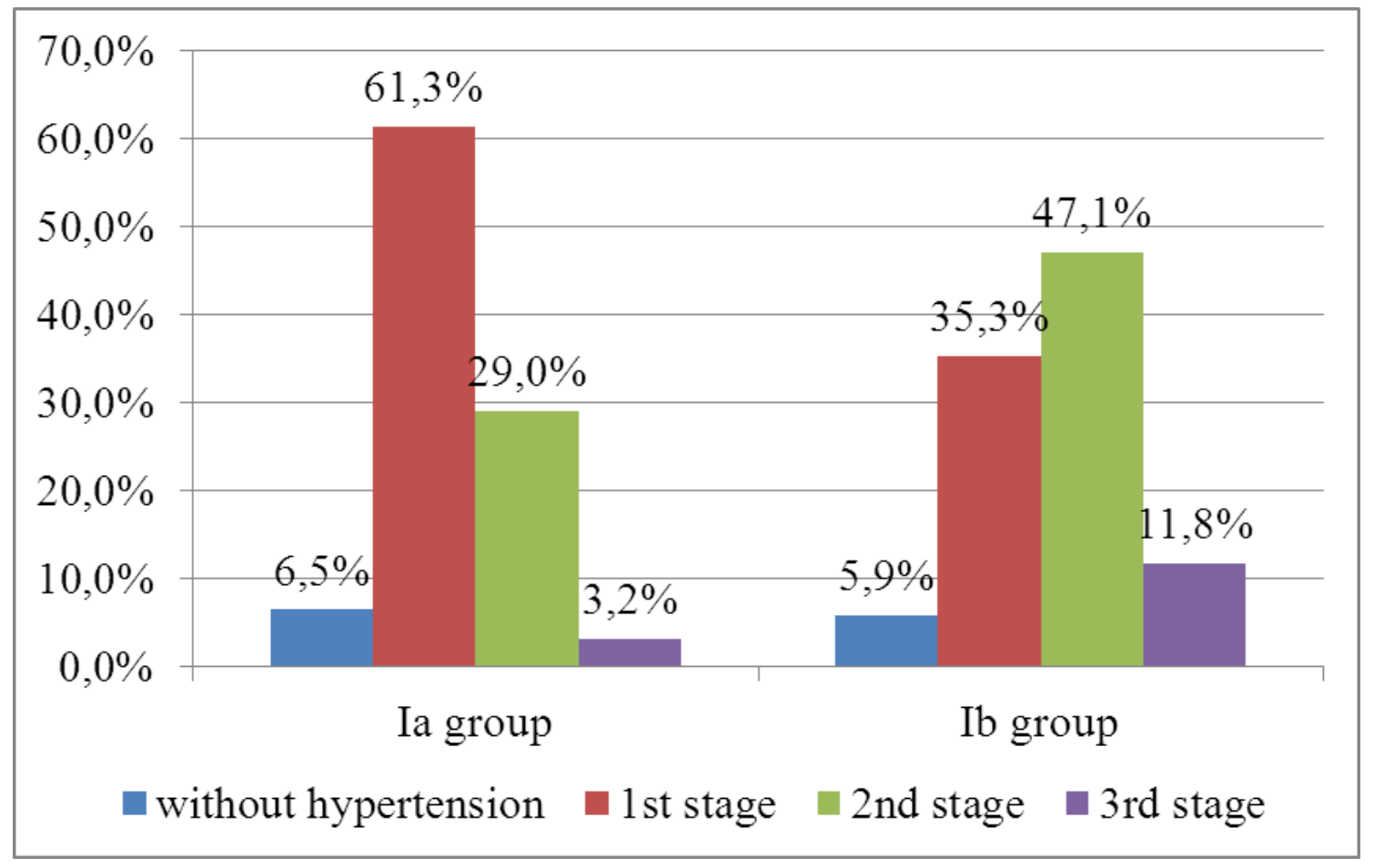

Fig. 2. Frequency of hypertension depending on the type of UCTD

Hypertension was found almost with the same frequency in both groups, but its structure differed based on stages. Stage 1 hypertension was detected in $19(61.3 \%)$ patients in the Ia group, stage 2 - in 9 $(29.0 \%)$ patients, stage 3 - in $1(3.2 \%)$. In Ib group, stage 1 hypertension was established in $6(35.3 \%)$ patients, stage 2 - in $8(47.1 \%)$, stage $3-$ in $2(11.8 \%)$. That is, an insignificant tendency to the development of more severe stages of hypertension due to the increase in number of phenotypic signs of
UCTD, in particular skeletal anomalies, is traced $(\chi 2=3.718 ; p=0,294)$.

The results of studies of FGF2 content in blood plasma are shown in tab. 2. All patients with diabetes included in the study have significantly higher median of the content of FGF2 than in the control ( $p<0.05$ by the Mann-Whitney criterion). The content of FGF2 was significantly higher in group I than such of controls or in group II $(p<0.05$ according to the Mann-Whitney criterion in both comparisons). No significant differences were observed between subgroups Ia and Ib, 
but there was a tendency for FGF2 to increase in patients of Ib group (with the presence of

visceral and skeletal symptoms of UCTD).

Table 2

FGF2 content in the blood of patients with type 2 diabetes and in control group (pg/ml)

\begin{tabular}{|c|c|c|c|}
\hline Groups & Me $\left[\mathrm{Q}_{25} ; \mathrm{Q}_{75}\right]$ & Min & Max \\
\hline All patients $(\mathrm{n}=90)$ & $28,1[18,7 ; 34,2]^{1}$ & 7,4 & 63,2 \\
\hline I group $(\mathrm{n}=48)$ & $30,8[21,6 ; 39,9]^{1,2}$ & 12,8 & 63,2 \\
\hline Ia group $(\mathrm{n}=31)$ & $30,3[22,6 ; 39,7]^{1,2}$ & 12,8 & 56,2 \\
\hline Ib group $(\mathrm{n}=17)$ & $31,4[20,5 ; 47,6]^{1,2}$ & 16,2 & 63,2 \\
\hline II group $(\mathrm{n}=42)$ & $22,1[16,2 ; 29,3]^{1}$ & 7,7 & 41,2 \\
\hline Control group $(\mathrm{n}=20)$ & $3,6[1,9 ; 9,0]$ & 0,8 & 19,6 \\
\hline
\end{tabular}

Notes: 1 - the differences are significant compared to the control ( $p<0,05$ according to the Mann-Whitney criterion). 2 - the differences are significant compared to the second group ( $p<0,05$ according to the MannWhitney criterion)

A correlation analysis of the FGF2 level in blood was performed separately in groups I and II (parametric Pearson method), which resulted in significant differences in the strength of the correlation relationships between the groups (tab. 3).

Table 3

Results of correlation analysis of FGF2 content and other indicators

\begin{tabular}{|l|c|c|c|c|}
\hline \multirow{2}{*}{ Indicators } & \multicolumn{2}{|c|}{ I group } & \multicolumn{2}{c|}{ II group } \\
\cline { 2 - 5 } & $r$ & $\mathrm{p}$ & $r$ & $\mathrm{p}$ \\
\hline Age, years & 0,107 & 0,227 & 0,649 & $<0,001$ \\
\hline Duration of DM, years & 0,059 & 0,877 & 0,357 & 0,020 \\
\hline Hypertension (0 - no, 1-3 st.) & 0,564 & 0,001 & 0,413 & 0,006 \\
\hline Diabetic nephropathy & 0,206 & 0,159 & 0,372 & 0,015 \\
\hline
\end{tabular}

Interesting differences have been identified as a result of the correlation analysis of FGF2 content and other indicators. The correlation of FGF2 depending on age and duration of diabetes mellitus was absent in group I $-r=0.107$ and $r=0.059$, respectively $(\mathrm{p}>0.05)$. On the contrary, a significant strong positive correlation was found between FGF2 and age $(r=0.649, \mathrm{p}<0.001)$ and duration of diabetes $(r=0.357, \mathrm{p}=0.02)$ in group II. These patterns are shown in fig. 3,4

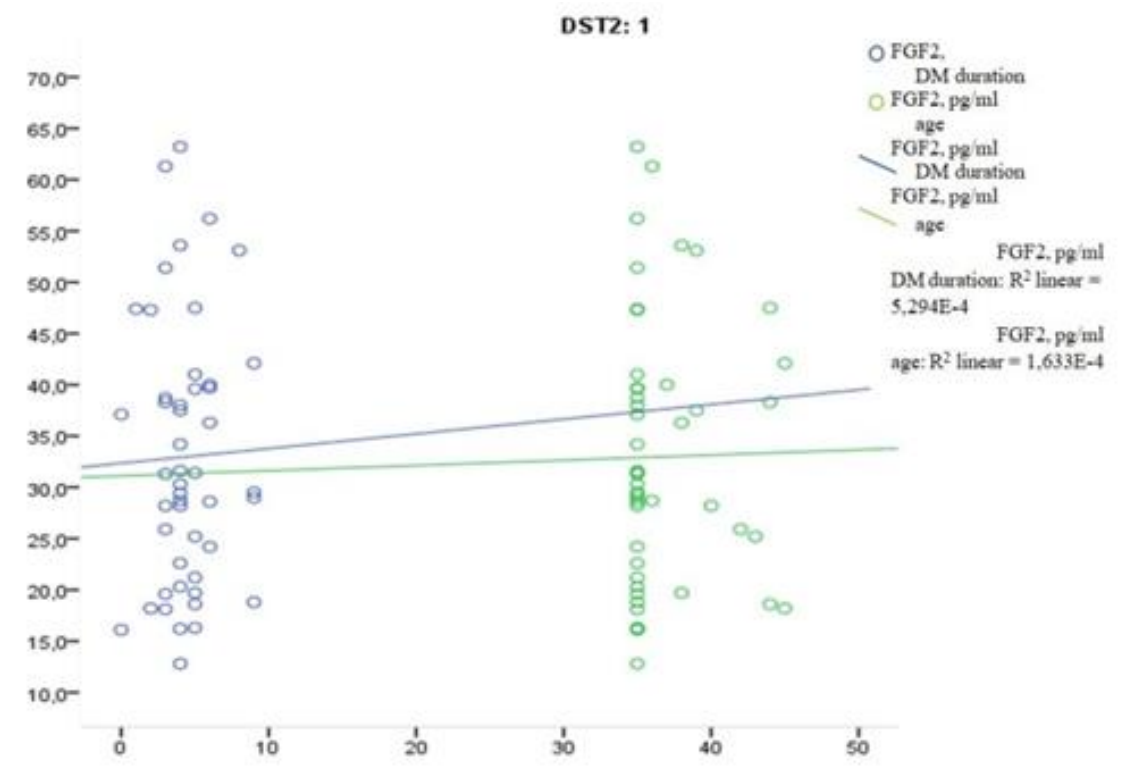

Fig. 3. Diagram of scattering of FGF2 dependence on age and duration of diabetes in I groups of patients 


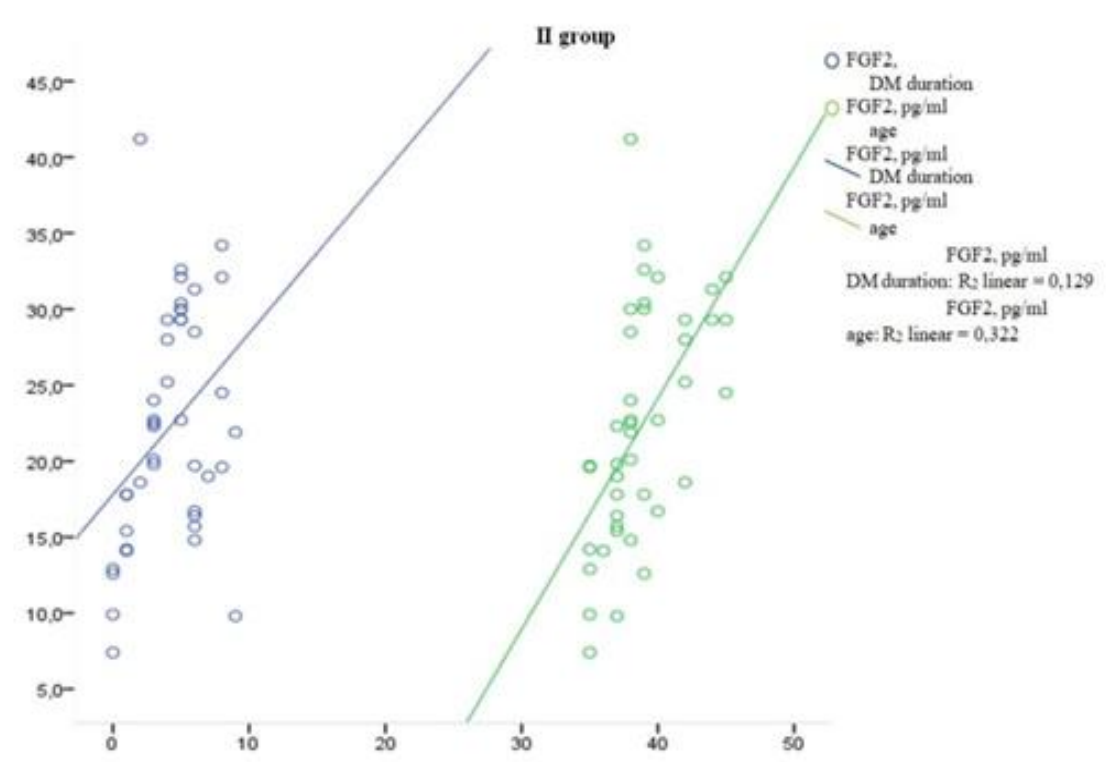

Fig. 4. Diagram of scattering of FGF2 dependence on age and duration of diabetes in II groups of patients

Data suggests that the content of FGF2 increases with age and during the course of the disease in patients with DM type 2. This dependence is absent in the presence of UCTD in patients with DM type 2, which can be explained by the initial increase in the content of FGF2 on the background of metabolic disorders of the connective tissue.

Another interesting regularity is the presence of a statistically significant correlation between the content of FGF2 in patients with diabetes with the presence and severity of hypertension in both groups $-r=$ $0.564(\mathrm{p}=0.001)$ and $r=0.413(\mathrm{p}=0.006)$ respectively in I and II groups.

Also, there was no significant positive correlation with the presence of diabetic nephropathy $-\mathrm{r}=0.206(\mathrm{p}=0.159)$ in patients with UCTD (group I). The correlation with the presence of diabetic nephropathy was significantly positive $r=$ $0.372(\mathrm{p}=0.015)$ in patients of the II group (without evidence of UCTD). In addition, the presence and severity of hypertension and diabetic nephropathy had correlations among themselves: in group I there was a significant positive correlation $-r=0.451(\mathrm{p}=0.001)$, and in the second group there was also a significant positive correlation $\mathrm{r}=0.506$ $(\mathrm{p}=001)$.

Thus, the presence of UCTD and increased content of FGF2 are associated with the development and progression of hypertension in patients with DM type 2, suggesting the possibility of using these indicators as predictors of hypertension. But for studying this possibility, dynamic observation for a long period since the debut of the DM is necessary. It is also needed to take into account the fairly high cost of immuno-enzymatic analysis of the content of FGF2. On the other hand, the content of FGF2 is closely related to the UCTD, therefore, the possibility of using clinical signs of UCTD to predict the development of hypertension in patients with type 2 diabetes has been tested.

To this end, an analysis of the written discharge reports after a previous inpatient treatment (from two to five years ago) was performed in patients with a duration of type 2 diabetes for at least 2 years. Such discharge reports were available in 78 patients.

The method of binary logistic regression (BLR) is used for the analysis of the possibilities of using the UCTD signs as predictors of hypertension. The patients included in this analysis were divided into two groups:

- I group - patients with DM type 2, in whom hypertension was not diagnosed during the previous hospitalizations and wasn't found during the last hospitalization, as well as patients who have no differences in degree of hypertension during the previous and last hospitalization -38 patients; 
- II group - patients with DM type 2, in whom hypertension was not diagnosed during the previous hospitalization, but during their last hospitalization hypertension was detected, as well as patients whose hypertension during the last hospitalization increased in comparison with the previous one -40 patients.

Groups are encoded in the order scale: I group - «0»; II group - «1».

In the logistics analysis, two indicators were introduced:

- presence of signs of UCTD, encoded as the sum of individual visceral and/or skeletal symptoms $-\mathrm{x}_{1}$.

- duration of DM type 2 in years $-\mathrm{x}_{2}$. This indicator was introduced due to the influence of the duration of diabetes in patients with type 2 diabetes, regardless of other indicators.

According to the results of the analysis, the following data was obtained using the BLR (tab. 4).

All regression coefficients of the indicators included in the equation are reliable, with the value of significance $<0.05$ for all indices and constant as an evidenced, while the regression coefficient of UCTD has a very high significance $<0.001$ and significantly higher than the duration of the DM. This indicates a rather high predictive value of UCTD in the development of hypertension.

\section{Results of regression analysis of the hypertension development} or progression in patients with type 2 diabetes

Table 4

\begin{tabular}{|c|c|c|c|c|}
\hline Indicator & $\mathrm{B}$ & S.E. & Wald Statistics & Sign. (p) \\
\hline $\mathrm{x}_{1}$ & 2,970 & 0,689 & 18,578 & 0,000 \\
\hline $\mathrm{x}_{2}$ & 0,470 & 0,204 & 5,320 & 0,021 \\
\hline Constant & $-4,520$ & 1,367 & 10,927 & 0,001 \\
\hline
\end{tabular}

Notes: $x_{1}$ - signs of UCTD; $x_{2}$ - duration of type 2 diabetes; $B$ - coefficient of regression B; S.E. - standard error of the regression coefficient; $p$ - level of significance of the regression coefficient.

The obtained data allow us to calculate the value of $\mathrm{z}$, which can be presented in this analysis as:

$$
\mathrm{z}=\mathrm{x}_{1} \cdot 2,970+\mathrm{x}_{2} \cdot 0,470+(-4,520)(1)
$$

Further calculation of the hypertension development or progression probability of is carried out according to the formula:

$$
P=\frac{1}{1+e^{-z}}
$$

The greater final value of $\mathrm{P}$ is, the greater likelihood of hypertension or its progression in patients with DM type 2. The critical value, which determines the patient with risk of hypertension, is 0.5 .

While checking the predictive ability of the generated equation to predict the onset or progression of hypertension, the following data are established (tab. 5)

Table 5

\begin{tabular}{|c|c|c|c|c|}
\hline \multirow{3}{*}{\multicolumn{2}{|c|}{ Observed value }} & \multicolumn{3}{|c|}{ Estimated value } \\
\hline & & \multicolumn{2}{|c|}{ Development of hypertension } & \multirow{2}{*}{ Percentage of correct } \\
\hline & & 0 (no) & 1 (yes) & \\
\hline \multirow{2}{*}{$\begin{array}{l}\text { Development of } \\
\text { hypertension }\end{array}$} & 0 (no) & 34 & 4 & 89,5 \\
\hline & 1 (yes) & 5 & 35 & 87,5 \\
\hline \multicolumn{2}{|c|}{ Total percentage } & & & 88,5 \\
\hline
\end{tabular}

Table of classification of observed and predicted values

Notes. Distinguishing value $=0.500$

The data obtained indicate that the predictive value of the negative outcome is $89.5 \%$, the predictive value of the positive result is $87.5 \%$, and the overall predictability is $88.5 \%$. In $34(87.2 \%)$ cases out of the 39 patients who had no development or 
progression of hypertension, patients received a correct prediction that characterizes the specificity of the BLR equation. A correct prognosis was obtained as well in $35(89.7 \%)$ cases out of the 39 patients who had hypertension or progression that characterizes the sensitivity of the BLR equation.

Sufficiently high values of predictability, specificity and sensitivity suggest that this method can be used to predict the onset or progression of hypertension in patients with type 2 diabetes and to identify patients who require active prophylaxis of hypertension, even in the absence of other cardiovascular risks.

\section{CONCLUSIONS}

1. The development of hypertension in patients with DM type 2 in combination with UCTD occurs earlier, is almost independent of the duration of diabetes, more pronounced hypertension is observed in patients with visceral and skeletal symptoms of UCTD. This is evidence of the role of UCTD in the pathogenesis of hypertension in patients with type 2 diabetes.
2. Essential role in the emergence and progression of hypertension in patients with DM type 2 is played by metabolic disorders of the connective tissue that manifests as clinical signs of UCTD. FGF2, which content is increased in patients with visceral and/or skeletal symptoms of UCTD, is involved in its pathogenesis.

3. The regression model of the prediction of hypertension in patients with DM type 2 with an assessment of the presence of UCTD signs and the duration of diabetes has a high prognosticity, specificity and sensitivity, which makes it possible to apply this method in clinical practice to determine patients with high risk of development of hypertension.

\section{PERSPECTIVES FOR FUTURE STUDIES}

The data limitation is the age group (from 35 to 45 years) and the duration of diabetes (less than 10 years). In addition, the forecasting results were obtained based on the analysis of retrospective data. More evidence may be obtained in a prospective study involving more patients with more extensive inclusion criteria.

\section{REFERENCES}

1. Campbell, N. R., Lackland, D. T., Niebylski, M. L., \& World Hypertension League and International Society of Hypertension Executive Committees. (2014). High blood pressure: why prevention and control are urgent and important - a 2014 fact sheet from the World Hypertension League and the International Society of Hypertension. The Journal of Clinical Hypertension, 16(8), 551-553. Available from: http://ishworld.com/news/a/WHL-and-ISH-Hypertension-Fact-Sheet.

2. Movahed, M. R., et al. «Strong independent association between obesity and essential hypertension». Clinical obesity 6.3 (2016): 189-192.

3. Redon J., Martinez F., Fabia M. J. The metabolic syndrom in hypertension. Manual of hypertension of the European Society of Hypertension. Edited by G. Mancia, G. Grassi and J. Redon. CRC Press, 2014: 433442.

4. Sirenko Ju. N, Radchenko A. D., Slashheva T. G. Stratifikacija riska pacientov s arterial'noj gipertenziej i saharnym diabetom 2-go tipa: rezul'taty ukrainskogo mnogocentrovogo observacionnogo issledovanija Status. Arterial'naja gipertenzija. 2014; 2: 9-19.

5. Horr S., Nissen S. Managing hypertension in type 2 diabetes mellitus. Best Pract Res Clin Endocrinol Metab. 2016; 30(3):445-454. DOI: 10.1016/j.beem.2016. 06.001.

6. Mogil'nickaja L. A, Man'kovskij B. N. Soderzhanie jendotelial'nogo monocitaktivirujushhego peptida-II u bol'nyh saharnym diabetom 1 tipa s mikroangiopatijami i arterial'noj gipertenziej. Saharnyj diabet. 2016; 19(4):309-314 DOI: 10.14341/DM7674.

7. Woodward M, Huxley R, Ueshima H, Fang X. The Asia pacific cohort studies collaboration: a decade of achievements. Glob Heart. 2012 Dec;7(4):343-51.

8. Mandosi, Elisabetta, et al. «Endothelial dysfunction markers as a therapeutic target for Sildenafil treatment and effects on metabolic control in type 2 diabetes». Expert opinion on therapeutic targets 19.12 (2015): $1617-1622$.

9. Lüscher, Thomas F., et al. «Endothelial Dysfunction and Hypertension». Vascular Endothelium in Human Physiology and Pathophysiology. CRC Press, 2014. 125-146.

10. Lotfy, Mohamed, et al. «Chronic complications of diabetes mellitus: A mini review». Current diabetes reviews 13.1 (2017): 3-10. 
11. Russo, Ilaria, and Nikolaos G. Frangogiannis. «Diabetes-associated cardiac fibrosis: cellular effectors, molecular mechanisms and therapeutic opportunities». Journal of molecular and cellular cardiology 90 (2016): 84-93.

12. Shakya S., Wang Y., Mack J. A., Maytin E. V. Hyperglycemia-induced changes in hyaluronan contribute to impaired skin wound healing in diabetes: review and perspective. Int J Cell Biol. 2015, Article ID 701738. http://dx.doi.org/10.1155/2015/701738.

13. Mohamed, Raafat, et al. "Transforming growth factor- $\beta 1$ mediated CHST11 and CHSY1 mRNA expression is ROS dependent in vascular smooth muscle cells». Journal of Cell Communication and Signaling (2018): 1-9.

14. Papasotiriou, Marios, et al. «Serum and urine markers of collagen degradation reflect renal fibrosis in experimental kidney diseases». Nephrology Dialysis Transplantation 30.7 (2015): 1112-1121.

15. Kishi, Fumi, et al. «Urinary type IV collagen excretion is involved in the decline in estimated glomerular filtration rate in the Japanese general population without diabetes: A 5-year observational study». PloS one 13.4 (2018): e0195523.

16. Kadurina T. I, Gorbunova V. N. Displazija soedinitel'noj tkani. Rukovodstvo dlja vrachej. SPb, Jelbi-SPb, 2009. $704 \mathrm{~s}$.

17. Gubanova M. V., Kalashnikova L. A., Dobrynina L. A., Shamtieva K. V., Berdalin A. B. Markery displazii soedinitel'noj tkani pri dissekcii magistral'nyh arterij golovy i provocirujushhie faktory dissekcii. Annaly klinicheskoj i jeksperimental'noj nevrologii. 2017; 11(4): 19-28. DOI: 10.18454/ACEN.2017.4.2.

18. Martynova A. I, Nechaeva G. I: red. Nacional'nye rekomendacii rossijskogo nauchnogo medicinskogo obshhestva terapevtov po diagnostike, lecheniju i reabilitacii pacientov s displazijami soedinitel'noj tkani. M.: OOO «Bionika-Media», 2016. $80 \mathrm{~s}$.

19. Shivapour, Daniel M., Phillip Erwin, and Esther SH Kim. «Epidemiology of fibromuscular dysplasia: a review of the literature». Vascular Medicine 21.4 (2016): 376-381.

20. Alimova I. L., Pashinskaja N. B., Pleskachevskaja T. A. Osobennosti techenija saharnogo diabeta 1 tipa u detej i podrostkov na fone displazii soedinitel'noj tkani. Medicinskij vestnik Severnogo Kavkaza. 2016; 11(2): 272-275. 